\title{
PERANAN PENGELOLAAN SUMBERDAYA LAHAN BERBASIS SOSIAL BUDAYA DI PROVINSI DAERAH ISTIMEWA YOGYAKARTA
}

\author{
Oleh: \\ Nurul Khotimah \\ Program Studi IImu Lingkungan, Fakultas Geografi UGM \\ Geografi, FISE UNY
}

\begin{abstract}
Abstrak
Pengelolaan sumberdaya lahan di Provinsi Daerah Istimewa Yogyakarta perlu mempertimbangkan potensi sosial budaya yang ada dalam masyarakatnya. Selain berbasis pada ekosistem, pendekatan sosial budaya merupakan salah satu pendekatan yang mampu mewujudkan pengelolaan sumberdaya lahan yang mandiri di Provinsi Daerah Istimewa Yogyakarta.

Potensi sumberdaya lahan yang ada, memerlukan ruang kelola dalam masyarakat dengan melibatkan peran serta masyarakat secara nyata dalam pelaksanaannya. Ruang kelola tersebut dapat berupa peran serta masyarakat dalam proses penataan ruang dan penentuan kebijakan pengelolaan sumberdaya lahan di wilayah ekosistem.

Partisipasi sosial budaya dari pihak-pihak berkepentingan akan menghasilkan rencana tata ruang yang lebih akomodatif terhadap kepentingan bersama yang "intangible" yang dinikmati bersama oleh banyak komunitas yang tersebar di seluruh wilayah ekosistem tersebut.
\end{abstract}

Kata Kunci: Pengelolaan, Sumberdaya Lahan, Sosial Budaya

\section{Pendahuluan}

Pengelolaan sumberdaya lahan berbasis sosial budaya di Provinsi Daerah Istimewa Yogyakarta salah satunya dapat dilihat dari proses perencanaan tata ruangnya. Proses perencanaan tata ruang tersebut pada dasarnya ditujukan untuk meningkatkan kesejahteraan penduduk yang ada di dalamnya. Pengembangan yang mengacu pada paradigma pembangunan berkelanjutan harus mengacu pada tiga aspek, yaitu ekologi, ekonomi, dan sosial. Paradigma ini secara tersirat menjelaskan bahwa perencanaan yang berkelanjutan harus mengacu upaya peningkatan ekonomi/taraf hidup/pendapatan daerah yang menghasilkan manusia dengan kondisi sosial dan budaya tinggi serta tetap terjaganya keserasian dan keselarasan lingkungan hidup. Oleh karena itu dalam melakukan perencanaan tata ruang berkelanjutan maka berbagai macam kepentingan harus diakomodir secara selaras dan seimbang. 
Dengan semakin meningkatnya jumlah penduduk, maka kepentingan akan penggunaan lahan di wilayah Daerah Istimewa Yogyakarta akan semakin beragam. Keberagaman kepentingan dapat menyebabkan terjadinya tumpang tindih maupun kesemrawutan dalam penggunaannya. Hal ini apabila tidak cukup mendapat perhatian dalam usaha perencanaan maupun pengelolaannya, maka pada gilirannya akan menambah tekanan terhadap lingkungan. Tekanan lingkungan yang melewati batas toleransi akan berdampak pada kerusakan lingkungan dan pada gilirannya akan berdampak kepada manusia dan makhluk hidup yang ada di dalamnya (Suwedi, 2003).

Konflik penggunaan lahan dapat terjadi akibat dari adanya benturan kepentingan antar sektoral dan pembangunan oleh pertambahan penduduk. Konflik penggunaan lahan tersebut misalnya perubahan lahan sawah, tegalan dan hutan menjadi daerah permukiman, pertokoan, perkantoran, jalan, dan sarana perhubungan. Oleh karena itu diperlukan upaya perencanaan secara terpadu berupa rencana umum tata ruang. Untuk mendukung upaya perencanaan diperlukan data sumberdaya alam, teknik analisis, dan pengolahan data yang tepat dan cepat serta model pendekatan perencanaan. Evaluasi kemampuan lahan merupakan salah satu upaya untuk memanfaatkan lahan (sumberdaya lahan) sesuai dengan potensinya. Penilaian potensi lahan sangat diperlukan terutama dalam rangka penyusunan kebijakan pemanfaatan lahan dan pengelolaan lahan secara berkesinambungan. Untuk menyusun kebijakan tersebut sangat diperlukan peta-peta yang salah satunya adalah peta kemampuan Iahan. Analisis dan evaluasi kemampuan lahan akan mendukung proses dalam penyusunan rencana penggunaan lahan di suatu wilayah yang disusun dengan cepat dan tepat sebagai dasar pijakan dalam mengatasi benturan pemanfaatan penggunaan lahan atau sumberdaya lahan (Worosuprojo, dkk., 1993).

Provinsi Daerah Istimewa Yogyakarta yang terdiri dari 4 kabupaten dan 1 kotamadya memiliki karakteristik dan fungsi ruang berbeda-beda. Kabupaten Sleman merupakan daerah hinterland dengan fungsi utama sebagai kawasan resapan bagi Kota Yogyakarta dan Kabupaten Bantul. Kota Yogyakarta sebagai kawasan pusat pemerintahan dan kegiatan ekonomi, sedangkan Kabupaten Bantul sebagai daerah penyuplai tenaga kerja bagi Kota Yogyakarta. Kabupaten Gunungkidul dengan karakteriktik topografi karst mempunyai fungsi ruang yang sangat berbeda dengan daerah lain di Provinsi Daerah Istimewa Yogyakarta. Kabupaten Kulonprogo merupakan rangkaian Pegunungan Menoreh dengan potensi alam yang lebih khas lagi di antara yang lain. Perbedaan karakteristik tersebut dapat dijadikan parameter awal untuk pengembangan sumberdaya lahan dengan berbasis sosial budaya masyarakat masing-masing kabupaten/kota di Daerah Istimewa Yogyakarta. 


\section{Gambaran Umum Provinsi Daerah Istimewa Yogyakarta}

Kondisi administrasi wilayah Provinsi Daerah Istimewa Yogyakarta terletak di bagian selatan dan tengah Pulau Jawa yang dibatasi oleh Samudera Hindia di bagian selatan dan Provinsi Jawa Tengah di bagian lainnya. Batas dengan Provinsi Jawa Tengah meliputi: Kabupaten Wonogiri di bagian tenggara, Kabupaten Klaten di bagian timur laut, Kabupaten Magelang di bagian barat laut, dan Kabupaten Purworejo di bagian barat.

Secara astronomis, Provinsi Daerah Istimewa Yogyakarta terletak antara $7^{\circ} 33^{\prime}-8^{\circ} 12^{\prime} \mathrm{LS}$ dan $110^{\circ} 00^{\prime}$ - $110^{\circ} 50^{\prime} \mathrm{BT}$. Komponen fisiografi yang menyusun Provinsi Daerah Istimewa Yogyakarta terdiri dari 4 (empat) satuan fisiografis, yaitu Satuan Pegunungan Selatan (Dataran Tinggi Karst) dengan ketinggian tempat berkisar antara 150 - 700 meter, Satuan Gunungapi Merapi dengan ketinggian tempat berkisar antara 80 - 2.911 meter, Satuan Dataran Rendah yang membentang antara Pegunungan Selatan dan Pegunungan Kulonprogo pada ketinggian 0 - 80 meter, dan Pegunungan Kulonprogo dengan ketinggian hingga 572 meter.

Kondisi fisik di Provinsi Daerah Istimewa Yogyakarta dapat ditinjau dari kondisi geografi, iklim, geologi, geomorfologi, jenis tanah, dan hidrologi daerahnya. Kondisi geografi daerah menjelaskan tentang posisi spasial daerah dalam kaitannya dengan daerah lain yang ada di sekitarnya, baik dalam hal luas wilayah, batas-batas wilayah, maupun batas-batas potensi sumberdaya alam kewilayahan. Penggambaran kondisi geografi daerah dapat dilakukan, baik dengan deskripsi tulisan maupun melalui presentasi peta wilayah.

Kondisi iklim suatu wilayah sangat berpengaruh pada potensi daerah bersangkutan, baik dalam potensi sumberdaya alam maupun potensi kebencanaan alam. Deskripsi klimatologis Provinsi Daerah Istimewa Yogyakarta dapat diuraikan dari curah hujan dan suhu udaranya. Kedua parameter iklim ini sangat berpengaruh pada potensi pengembangan sumberdaya alam, baik dilihat sebagai potensi cadangan alamiah maupun potensi alam berkesinambungan. Curah hujan sebagai input air ke permukaan bumi membawa akibat pada variasi potensi hidrologi daerah bersangkutan, sehingga uraian hidrologi daerah tidak boleh dipisahkan dengan kondisi klimatologisnya, terutama dengan curah hujan. Air hujan yang jatuh ke permukaan bumi akan mengalami proses-proses evaporasi (kembali ke atmosfer sebagai uap air), infiltrasi (menjadi air tanah), dan genangan/limpasan (sebagai air permukaan).

Potensi air tanah dan keberadaan air permukaan satu daerah tidak sama dengan daerah lainnya walaupun keduanya mempunyai curah hujan yang sama. Hal ini disebabkan kondisi lahan (geologi, geomorfologi, dan tanah) setiap daerah berbeda. Perbedaan-perbedaan ini akhirnya membawa keberagaman dalam potensi sumberdaya alam dan potensi kebencanaan alam sehingga pengembangan sumberdaya alam daerah harus memperhatikan potensi-potensi alam tersebut. 
Pengembangan suatu potensi sumberdaya alam harus memperhatikan sifat dari sumberdaya yang akan dikembangkan, yaitu apakah sumberdaya alam tersebut berupa cadangan (tak terbaharui, misalnya tambang mineral/batuan) atau sebagai sumberdaya alam yang terbaharui (terbaharui, misalnya biota). Dengan kata lain, pengembangan sumberdaya alam harus memperhatikan kesinambungan pemanfaatan dan kelestarian lingkungan. Kekeliruan pengembangan sumberdaya alam selain berdampak pada degradasi sumberdaya alam bersangkutan juga berperan dalam memicu terjadinya bencana alam yang berakibat sangat merugikan.

Dalam era pembangunan yang semakin kompetitif dan adanya penerapan otonomi daerah, setiap daerah mempunyai hak untuk mengelola dan mendapatkan keuntungan dari sumberdaya alam asli daerah secara lebih leluasa dalam peningkatan pendapatan penduduknya. Daerah Istimewa Yogyakarta yang memiliki keanekaragaman lingkungan fisik dan potensi sumberdaya alam bervariasi, seperti pertanian, kehutanan, kelautan dan perikanan, serta pertambangan dan energi juga dapat mengembangkannya.

\section{Potensi Sosial Budaya}

Provinsi Daerah Istimewa Yogyakarta secara historis memiliki keunikan tersendiri, terutama sebagai ibukota kerajaan Mataram Islam pertama saat didirikan dan kemudian dilanjutkan dengan kerajaan Mataram Islam kedua yang masih terpelihara hingga kini. Selain memiliki latar belakang sejarah panjang sebelum kemerdekaan Indonesia, ternyata juga dilanjutkan pada masa-masa awal kemerdekaan, yaitu saat mempertahankan kemerdekaan, dimana secara nyata Yogyakarta menjadi ibukota negara. Selain latar belakang sejarah, Yogyakarta sebagai daerah istimewa juga memiliki keistimewaan dalam hal kepemimpinan, pertanahan, kebudayaan, keuangan, dan tata ruang wilayah. Di dalam bidang kebudayaan setidaknya dapat ditunjukkan melalui aspek bahasa, filosofi dan budaya simbol, kesenian (seni musik dan tari, seni bangunan/arsitektur, seni rupa dan seni kriya), makanan dan minuman (kuliner), dan pakaian (Dwiyanto, 2009).

Bahasa daerah yang digunakan adalah Bahasa Jawa yang berakar dari wilayah ini dan masih digunakan dalam percakapan sehari-hari di kalangan masyarakat. Untuk mencegah lunturnya penggunaan Bahasa Jawa, khususnya di lingkungan pemerintahan dan pendidikan formal, maka telah ditetapkan melalui peraturan tentang penggunaan Bahasa Jawa pada hari tertentu (Sabtu) terutama dalam bertutur dan bertegur sapa (termasuk rapat) dan penerimaan telepon. Selain itu melalui Dinas Kebudayaan Provinsi DIY juga disiapkan program kegiatan yang mendukung pelestarian dan pengembangan penggunaan Bahasa Jawa.

Secara filosofis pembangunan di DIY didasarkan atas falsafah "hamemayu hayuning bawana", menjaga keselamatan agar dunia ini tetap 
lestari dan harmonis sebagai cita-cita luhur untuk mewujudkan tata nilai kehidupan masyarakat Yogyakarta berdasarkan nilai budaya. Filosofi ini kemudian dijabarkan dalam simbol operasional yang berbunyi "golong-gilig, sawiji, greget, sengguh, ora mingkuh". Semangat golong-gilig adalah simbol bersatu padu, sedangkan ajaran moral sawiji adalah menyatu/mengabdi hanya kepada Yang Maha Esa. Sementara itu greget, sengguh, ora mingkuh adalah rangkaian kata yang menggambarkan kredo penuh semangat, berkonsentrasi penuh, dan tidak menyeleweng. Secara fisik filosofi itu tergambar dalam tata ruang wilayah yang dikenal dengan "sumbu imajiner" yang terdiri atas Kraton, tugu 'pal putih', dan Gunung Merapi ke arah Utara, sedangkan Kraton, Panggung Krapyak, dan Samudra Indonesia ke arah selatan. Pandangan kosmologis ini menggambarkan bahwa pertemuan antara sifat-sifat kelakilakian (gunung jika makro dan tugu jika mikro) dengan sifat-sifat keperempuanan (panggung krapyak/yoni jika mikro dan laut jika makro) akan melahirkan kesuburan atau penciptaan.

Berbagai bentuk kesenian yang tercipta bersamaan dengan keberadaan pusat-pusat kebudayaan lama hingga kini terus berkembang di wilayah DIY meliputi seni murni (seni rupa dan seni kriya), seni pertunjukan (seni musik dan seni tari), dan seni bangunan (arsitektur). Perkembangan ini didukung pula oleh banyaknya sekolah dan perguruan tinggi seni serta sanggar-sanggar seni. Pemerintah Provinsi DIY juga memberikan fasilitas berupa wadah untuk mengekspresikan inovasi dan kreasi-kreasi seni serta pemberian penghargaan bagi prestasi-prestasi seni dari seluruh jenis dan cabang kesenian.

Di dalam khasanah makanan dan minuman (kuliner), Yogyakarta juga telah dikenal sebagai 'kota gudeg' dan bakpia. Di daerah ini terdapat begitu banyak sentra-sentra makanan utama seperti gudeg dan bakpia, selain jenis makanan lain yang beraneka bahan, warna, rasa, dan penyajiannya. Pemerintah provinsi dan daerah kabupaten/kota juga memfasilitasi pelestarian dan pemberdayaan makanan lokal ini dengan menyelenggarakan festival secara berkala serta mempelopori penyajian makanan tradisional dalam pertemuan-pertemuan formal maupun informal.

Salah satu artefak yang biasa digunakan untuk memberikan identitas lokal adalah pakaian atau busana. Yogyakarta dengan pusat kebudayaan klasik Kraton Yogyakarta telah cukup lama dikenal dengan busana tradisional Jawa berupa kain dengan beskap, surjan, dan destar/mondolan (ikat kepala) serta kelengkapannya. Jenis pakaian ini telah merambah luas di kalangan masyarakat untuk berbagai keperluan. Selain itu Yogyakarta juga dikenal sebagai salah satu pusat pertumbuhan batik nusantara yang memiliki ciri khas 'gaya Yogyakarta'. Pelestarian, pembinaan, dan pengembangan batik telah dilakukan secara sinergis antara masyarakat dengan pemerintah, sehingga terbentuk paguyuban-paguyuban pecinta batik dan menyelenggarakan berbagai event budaya secara berkala. 
Aset budaya yang dimiliki meliputi budaya yang bersifat fisik (tangible) dan non-fisik (intangible). Kondisi budaya fisik (tangible) meliputi: kawasan cagar budaya berjumlah 13 Kawasan Cagar Budaya (KCB). Potensi Benda Cagar Budaya yang dimiliki sebanyak 365 buah (Dwiyanto, 2009). Potensi museum yang dimiliki baik museum negeri maupun museum swasta berjumlah 30 museum, yang terdiri dari 14 museum Benda Cagar Budaya dan Kesenian, 7 museum Pendidikan dan IImu Pengetahuan serta 9 museum Perjuangan. Keberadaan museum di Kota Yogyakarta 18 buah, di Kabupaten Sleman 9 buah, di Kabupaten Bantul 2 buah, dan di Kabupaten Gunungkidul 1 buah.

\section{Pengelolaan Sumberdaya Lahan Berbasis Sosial Budaya}

Ketergantungan dan ketidakterpisahan antara pengelolaan sumberdaya dan keanekaragaman hayati Bangsa Indonesia dengan sistem-sistem sosial lokal yang hidup di tengah masyarakat dapat secara jelas dilihat dalam kehidupan sehari-hari di daerah pedesaan, baik dalam komunitas-komunitas masyarakat adat maupun dalam komunitas-komunitas lokal lainnya yang masih menerapkan sebagian dari sistem sosial berlandaskan pengetahuan dan caracara kehidupan tradisional.

Indonesia memiliki berbagai sumberdaya dan keanekaragaman hayati yang sangat melimpah sehingga sangat penting dan strategis artinya untuk keberlangsungan kehidupannya sebagai "bangsa". Beragamnya keanekaragaman hayati ini bukan semata-mata karena posisi Negara Indonesia sebagai salah satu negara kaya di dunia dalam keanekaragaman hayati (mega-biodiversity), akan tetapi justru karena keterkaitannya yang erat dengan kekayaan keanekaragaman budaya lokal yang dimiliki bangsa ini (mega-cultural diversity).

Para pendiri negara-bangsa (nation-state) Indonesia sejak semula sudah menyadari bahwa negara ini adalah negara kepulauan yang majemuk sistem politik, sistem hukum dan sosial-budayanya. Semboyan "Bhinneka Tunggal Ika" secara filosofis menunjukkan penghormatan bangsa Indonesia atas kemajemukan atau keberagaman sistem sosial yang dimilikinya.

Sistem-sistem lokal ini berbeda satu sama lain sesuai kondisi sosial budaya dan tipe ekosistem setempat. Mereka umumnya memiliki sistem pengetahuan dan pengelolaan sumberdaya lokal yang diwariskan dan ditumbuh-kembangkan terus-menerus secara turun temurun. Dari keberagaman sistem-sistem lokal ini bisa ditarik beberapa prinsip-prinsip kearifan tradisional yang dihormati dan dipraktekkan oleh komunitaskomunitas masyarakat adat, yaitu antara lain:

1. Ketergantungan manusia dengan alam yang mensyaratkan keselarasan hubungan dimana manusia merupakan bagian dari alam itu sendiri yang harus dijaga keseimbangannya. 
2. Penguasaan atas wilayah adat tertentu bersifat eksklusif sebagai hak penguasaan dan/atau kepemilikan bersama komunitas (comunal property resources) atau kolektif yang dikenal sebagai wilayah adat (di Maluku dikenal sebagai petuanan, di sebagian besar Sumatera dikenal dengan ulayat dan tanah marga, dan di Yogyakarta disebut Magersari/Sultan Ground) sehingga mengikat semua warga untuk menjaga dan mengelolanya untuk keadilan dan kesejahteraan bersama serta mengamankannya dari eksploitasi pihak luar. Banyak contoh kasus menunjukkan bahwa keutuhan sistem kepemilikan komunal atau kolektif ini bisa mencegah munculnya eksploitasi berlebihan atas lingkungan lokal.

3. Sistem pengetahuan dan struktur pengaturan ('pemerintahan') adat memberikan kemampuan untuk memecahkan masalah-masalah yang mereka hadapi dalam pemanfaatan sumberdaya lahan.

4. Sistem alokasi dan penegakan hukum adat untuk mengamankan sumberdaya milik bersama dari penggunaan berlebihan, baik oleh masyarakat sendiri maupun oleh orang di luar komunitas.

5. Mekanisme pemerataan distribusi hasil "panen" sumberdaya alam milik bersama yang bisa meredam kecemburuan sosial di tengah-tengah masyarakat.

Untuk menjamin keberlanjutan fungsi layanan sosial-ekologi dan keberlanjutan sumberdaya alam dalam cakupan wilayah yang lebih luas maka pendekatan perencanaan sumberdaya alam dengan instrumen penataan ruang harus dilakukan dengan mempertimbangkan bentang alam dan kesatuan layanan ekosistem, endemisme dan keterancaman kepunahan flora-fauna, aliran-aliran energi sosial dan kultural, kesamaan sejarah dan konstelasi geopolitik wilayah (Nababan, 2003).

Dengan pertimbangan-pertimbangan ini maka pilihan-pilihan atas sistem budidaya, teknologi pemungutan/ekstraksi sumberdaya alam dan pengolahan hasil harus benar-benar mempertimbangkan keberlanjutan ekologi dari mulai tingkat ekosistem lokal sampai ekosistem regional yang lebih luas. Dengan pendekatan ekosistem yang diperkaya dengan perspektif kultural seperti ini tidak ada lagi "keharusan" untuk menerapkan satu sistem pengelolaan sumberdaya alam untuk wilayah yang luas. Hampir bisa dipastikan bahwa setiap ekosistem bisa jadi akan membutuhkan sistem pengelolaan sumberdaya alam yang berbeda dari ekosistem di wilayah lain.

\section{Peran Serta Masyarakat dalam Pengelolaan Sumberdaya Lahan}

Tantangan terbesar bagi pengelolaan sumberdaya alam adalah menciptakan, kemudian mempertahankan keseimbangan antara pemenuhan kebutuhan manusia dan keberlanjutan pemanfaatan dari keberadaan sumberdaya alam. Hal ini dikarenakan pada saat ini yang terjadi adalah 
pemenuhan kebutuhan manusia yang berlebihan telah menyebabkan semakin berkurangnya sumberdaya alam.

Hingga saat ini pengelolaan sumberdaya alam masih belum memberikan nilai yang cukup berarti bagi peningkatan kesejahteraan masyarakat. Degradasi sumberdaya alam sebagian besar disebabkan oleh menguatnya krisis persepsi yang bersumber pada paradigma pengelolaan sumberdaya alam yang berorientasi pada pertumbuhan ekonomi jangka pendek dan terlalu memanjakan kepentingan manusia.

Hal ini dapat dibenahi melalui perubahan paradigma sektoral menjadi terpadu. Koordinasi dan kerjasama antar sektor harus berbasis pemberdayaan masyarakat, sehingga partisipasi masyarakat sebagai mitra dalam pembangunan sosial ekonomi menjadi penting dan diawali dengan pemberdayaan masyarakat lokal.

Menurut Horoepoetri (1992), pemanfaatan sumberdaya alam harus memperhatikan patokan sebagai berikut:

1. Daya guna dan hasil guna yang dikehendaki harus dilihat dalam batasbatas yang optimal sehubungan dengan kelestarian sumberdaya yang mungkin dicapai.

2. Tidak mengurangi kemampuan dan kelestarian sumberdaya lain yang berkaitan dalam suatu ekosistem.

3. Memberikan kemungkinan untuk mengadakan pilihan penggunaan dalam pembangunan di masa depan.

Oleh karena itu keterlibatan masyarakat menjadi hal yang mutlak dilakukan. Pelibatan masyarakat dalam pengelolaan lingkungan dan sumberdaya sangat berguna karena dapat:

1. Merumuskan persoalan dengan lebih efektif.

2. Mendapatkan informasi dan pemahaman di luar jangkauan dunia ilmiah.

3. Merumuskan alternatif penyelesaian masalah yang secara sosial dapat diterima.

4. Membentuk perasaan memiliki terhadap rencana dan penyelesaian, sehingga memudahkan penerapan.

Peran serta masyarakat adalah sebagai proses komunikasi dua arah yang terus menerus untuk meningkatkan pengertian masyarakat atas suatu proses dimana masalah-masalah dan kebutuhan lingkungan sedang dianalisa oleh badan yang bertanggung jawab. Secara sederhana didefinisikan sebagai feed-forward information (komunikasi dari pemerintah kepada masyarakat tentang suatu kebijakan) dan feed-back information (komunikasi dari masyarakat ke pemerintah atas kebijakan itu) (Canter, 1977 dalam Horoepoetri, 1992).

Dengan melibatkan masyarakat yang potensial terkena dampak dari kebijakan, para pengambil keputusan dapat menangkap pandangan, kebutuhan dan pengharapan dari masyarakat dan menuangkannya ke dalam 
konsep. Pandangan dan reaksi masyarakat itu akan menolong pengambil keputusan untuk menentukan prioritas, kepentingan dan arah yang positif dari berbagai faktor.

Horoepoetri (1992) juga mengemukakan agar peran serta masyarakat dapat menjadi efektif dan berdaya guna, perlu dipenuhi syarat-syarat sebagai berikut:

1. Pemastian penerimaan informasi dengan mewajibkan pemrakarsa kegiatan mengumumkan rencana kegiatannya.

2. Informasi lintas batas, masalah lingkungan tidak mengenal batas wilayah.

3. Informasi tepat waktu, peran serta masyarakat membutuhkan informasi sedini dan seteliti mungkin, sehingga bisa dibuat alternatif-alternatif.

4. Informasi yang lengkap dan menyeluruh.

5. Informasi yang dapat dipahami.

\section{Penutup}

Dalam mengkaji dan mencermati potensi dari kedua komponen (sumberdaya alam dan kondisi sosial budaya masyarakat) yang dimiliki oleh Provinsi Daerah Istimewa Yogyakarta maka ada beberapa pertimbangan yang dapat digunakan sebagai dasar dalam perencanaan dan pengembangan wilayah, yaitu:

1. Dilihat dari kondisi wilayah, Provinsi Daerah Istimewa Yogyakarta memiliki wilayah yang strategis, yaitu membentang dari Utara (Gunung Merapi) sampai ke Selatan (pesisir dan laut) yang juga merupakan satu kesatuan daerah aliran sungai (DAS) Progo - Opak - Oyo yang secara administrasi relatif banyak mendapat pengaruh dari daerah di sekitarnya. Hal ini akan lebih memerlukan adanya koordinasi dalam melakukan manajemen penggunaan lahan dan air sungai terutama sungai Progo. Berdasarkan komponen lahan, Provinsi Daerah Istimewa Yogyakarta memiliki lahan yang sangat potensial untuk dapat dikembangkan menjadi lahan perkebunan, pertanian, perumahan, dan lahan pertambangan.

2. Kegiatan di sektor agrobisnis dan agrowisata merupakan potensi yang paling besar untuk dikembangkan karena selain didukung oleh suburnya wilayah Daerah Istimewa Yogyakarta, juga didukung melimpahnya sumberdaya air, kondisi iklim dan lingkungan yang kondusif, juga didukung oleh tingkat sosial budaya masyarakatnya yang sebagian besar adalah pelajar, petani dan buruh tani.

3. Dari jumlah penduduk dengan mata pencaharian petani yang cukup besar, maka penggalakan kegiatan ekonomi yang terkait dengan kegiatan 
agrobisnis dan agrowisata seperti: penciptaan pasar, pembangunan agrowisata, peningkatan ketrampilan dan permodalan perlu menjadi prioritas di dalam perencanaan.

4. Dilihat dari kekuatan sumberdaya mineral golongan $\mathrm{C}$, ada beberapa potensi yang dapat diusahakan/digali guna meningkatkan kegiatan ekonomi, walaupun masih sekedar cadangan terindikasi. Penggalakan promosi potensi wilayah dan peningkatan kegiatan ekplorasi (disamping eksploitasi) di sektor pertambangan di Daerah Istimewa Yogyakarta perlu ditingkatkan guna mengetahui secara detail potensi cadangan pertambangan yang belum tergali. Hal ini dapat pula digunakan untuk memprediksi besarnya dukungan perekonomian dari sektor pertambangan di masa mendatang.

5. Potensi mutu pendidikan dan mutu sumberdaya manusia juga harus menjadi potensi mengurangi ketergantungan pada kegiatan agrobisnis semata (apabila ternyata potensi sumberdaya mineralnya habis), yang akan berdampak pada peningkatan kegiatan di sektor jasa, perbankan, konsultasi maupun industri tinggi yang berbasis pada kebutuhan tenaga terampil.

\section{Daftar Pustaka}

Dwiyanto, Djoko. (2009). Potensi Budaya dan Peluang Kerjasama Yogyakarta dan Suriname. Dinas Kebudayaan Provinsi DIY.

Horoepoetri, Arimbi. (1992). Peran Serta Masyarakat dalam Pengelolaan Lingkungan. http://dev.pacific.net.id. 3 Januari 2010.

Nababan, Abdon. (2003). Pengelolaan Sumberdaya Alam Berbasis Masyarakat Adat: Tantangan dan Peluang. Makalah Pelatihan Pengelolaan Lingkungan Hidup di Daerah. Pusat Penelitian Lingkungan Hidup. IPB. Bogor.

Suwedi, Nawa. (2003). Pengembangan Sistem Informasi Sumberdaya Alam dan Sosial Budaya Bagi Perencana Daerah (Studi Kasus Kabupaten Pemalang). Prosiding Seminar Teknologi untuk Negeri Tahun 2003, Vol. V, hal. 122 - 129. HUMAS-BPPT/ANY.

Worosuprojo, Suratman, dkk. (1993). Evaluasi Kemampuan Lahan untuk Perencanaan Penggunaan Lahan dengan Metode GIS di Provinsi Daerah Istimewa Yogyakarta. Kerjasama Fakultas Geografi UGM Yogyakarta dengan Program CRC Press. London. Halaman 51 - 61. 